\title{
JUURNAL.RU
}

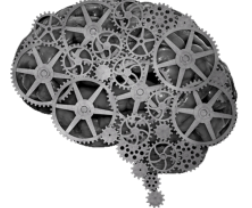

COMPANY GROUP "INTELLEKT"

\author{
Чубка С.А., Бойко Н.В. \\ Поликлиника № 1 \\ Таганрог, Россия \\ Ростовский государственный медицинский университет \\ Ростов-на-Дону, Россия
}

doi: 10.18411/1j2016-4-49

\section{Причины рецидивирующего течения экссудативного среднего отита}

Экссудативный средний отит (ЭСО) - часто встречающееся заболевание как среди детского, так и среди взрослого населения. Высокому уровню заболеваемости ЭСО способствуют увеличение частоты острых респираторновирусных инфекций, рост иммунодефицитных состояний среди населения, широкое, не всегда обоснованное применение антибиотиков, в том числе, при остром гнойном среднем отите до образования перфорации. Предрасполагающими факторами являются гипертрофия глоточной и/или трубных миндалин, рубцовые изменения в носоглотке вследствие перенесенной ранее аденотомии, деформация и дефекты перегородки носа, гипертрофия задних концов нижних носовых раковин и другие $[1,2]$. Кондуктивная тугоухость сопровождает и зияние слуховой трубы [3].

Основной причиной ЭСО является дисфункция слуховой трубы, приводящая к нарушению аэрации барабанной полости, развитию отрицательного давления в ней, что вызывает транссудацию, а затем резорбцию жидкой части транссудата. По мере повышения вязкости содержимого барабанной полости эвакуация его через слуховую трубу становится все более затрудненной.

Целью нашего исследования было изучение причин рецидивирующего течения экссудативного среднего отита.

Материалы и методы исследования. Мы наблюдали 12 больных с ЭСО в 
возрасте от 14 до 67 лет с рецидивирующим ЭСО. Количество рецидивов - от 2 до 4 на протяжении 1-6 лет Всем больным, помимо общеклинического исследования, произведена тональная пороговая аудиометрия, тимпанометрия, исследование функции слуховой трубы, эндоскопическое исследование полости носа и носоглотки. Типы тимпанограмм определяли в соответствии с классификацией Jerger (1970): тип A - нормальная аэрация барабанной полости, тип В - наличие жидкости в барабанной полости, тип С - нарушение вентиляции барабанной полости с отрицательное давление в ней. При аудиологическом исследовании у всех наблюдаемых больных обнаружена кондуктивная тугоухость, причем у 7 снижение слуха было двусторонним, симметричным, а у 5 - односторонним. У 9 больных повышение порогов слуха по воздушной проводимости было в пределах 30 дб, у 3 - от 30 до 45 дб. При тимпанометрии патологические типы кривых получены при исследовании всех 12 больных (19 ушей): тимпанограмма типа В - в 19 исследованиях.

Лечение ЭСО включало в себя три составляющих: 1) устранение причины тубарной дисфункции; 2) удаление содержимого барабанной полости - мукоида и создание условий для его последующей эвакуации; 3) терапевтическое воздействие, направленное на нормализацию слизистой оболочки среднего уха с назначением лекарственных препаратов, облегчающих эвакуацию содержимого барабанной полости через слуховую трубу (флюдитек, эреспал).

После курса консервативного лечения 11 больных (14 ушей) было подвергнуто шунтированию. При вскрытии барабанной полости во всех случаях был обнаружен густой вязкий экссудат (мукоид), с трудом эвакуированный при помощи электроотсоса. Следует отметить, что у 9 из 12 шунтированных больных до вмешательства продуть слуховую трубу не удавалось даже после тщательной анемизации, с глотком. Сразу после тимпанотомии проходимость слуховой трубы восстановилась у всех больных и уже на операционном столе стало возможно самопродувание, что облегчало эвакуацию мукоида. Отделяемое из шунта сохранялось в среднем в течение недели, прогрессивно уменьшаясь в ко- 
личестве. В последующем шунт оставляли на 2 - 6 месяцев с рекомендацией избегать попадания в ухо воды. Сроки последующего наблюдения - от 6 месяцев до 4 лет.

Анализ причин рецидивов ЭСО выявил следующие факторы: круглогодичный аллергический ринит в сочетании с бронхиальной астмой - у 6 больного, дефект задних отделов сошника (вероятно, врожденный) - у 1 больного, наличие остатков аденоидной ткани на боковых стенках носоглотки - у 3 больного, тубарная дисфункция неустановленного генеза - у 2 больных. Наряду с традиционными отоскопическими признаками при рецидивах ЭСО отмечено появление ретракционных карманов 1 или 2 типа. Больным с круглогодичным аллергическим ринитом был назначен 5 - дневный курс системной гормонотерапии (преднизолон по 20 мг в сутки 1 раз в день, утром), что привело к исчезновению симптомов ЭСО. Назначение коротких курсов преднизолона было использовано еще у 2 больных при первичном шунтировании при длительной, обильной экссудации.

Таким образом, рецидивы ЭСО обусловлены долгосрочным сохранением факторов, обусловливающих тубарную дисфункцию.

\section{Литература:}

1. Бойко Н.В., Бачурина А.С. Аденотомия и аденотонзиллотомия у детей с затруднением носового дыхания. Рос. ринология 2015; 23 (1): 9-12.

2. Бойко Н.В. Врожденные дефекты сошника. Рос. ринология. 2014. Т.22. № 1. C. 24-25.

3. Бойко Н.В., Колесников В.Н. Роль эндоскопического исследования носоглотки в диагностике синдрома зияющей слуховой трубы. Рос. ринология. 2014. T. 22. № 2. C. 33-34. 